\title{
Obstetric care providers' knowledge, practice and associated factors towards active management of third stage of labor in Sidama Zone, South Ethiopia
}

Zelalem Tenaw ${ }^{1 *}$, Zemenu Yohannes ${ }^{1}$ and Abdela Amano ${ }^{2}$

\begin{abstract}
Background: Active management of third stage of labor played a great role to prevent child birth related hemorrhage. However, maternal morbidity and mortality related to hemorrhage is high due to lack of knowledge and skill of obstetric care providers 'on active management of third stage of labor.

Our study was aimed to assess knowledge, practice and associated factors of obstetric care providers (Midwives, Nurses and Health officers) on active management of third stage of labor in Sidama Zone, South Ethiopia.

Methods: An institution based cross sectional study design was conducted from December 1-30/2015 among midwives, nurses and health officers. Simple random sampling technique was used to get the total of 528 participants. Data entry was done using EPI Info 3.5.1 and exported to SPSS version 20.0 software package for analysis. The presence of association between independent and dependent variables was assessed using odds ratio with 97\% confidence interval by applying logistic regression model.

Results: Of the 528 obstetric care providers $37.7 \%$ and $32.8 \%$ were knowledgeable and skilled to manage third stage of labor respectively. After controlling for possible confounding factors, the result showed that pre/in service training, being midwife and graduation year were found to be the major predictors of proper active management of third stage of labor.

Conclusion: The knowledge and practice of obstetric care providers towards active management of third stage of labor can be improved with appropriate interventions like in-service trainings. This study also clearly showed that the level of knowledge and practice of obstetric care providers to wards active management of third stage of labor needs immediate attention of Universities and health science colleges better to revise their obstetrics course contents, health institutions and zonal health bureau should arrange trainings for their obstetrics care providers to enhance skill.
\end{abstract}

Keywords: Active management of third stage of labor, Ethiopia, Knowledge, Practice, Third stage

\footnotetext{
* Correspondence: abigiatenaw@gmail.com

${ }^{1}$ School of Nursing and Midwifery, College of Medicine and health sciences,

Hawassa University, Hawassa, Ethiopia

Full list of author information is available at the end of the article
} 


\section{Background}

Active management of third stage of labor played a great role to prevent childbirth related hemorrhage. Proper practice of active management of third stage of labor is a novel method to alleviate postpartum hemorrhage [1, 2].

Hemorrhage is the leading cause of maternal death, especially in developing countries including Ethiopia. Maternal mortality ratio in Ethiopia per 100,000 live births were 676 in 2012 and 420 in 2014. A 2015 estimate puts the maternal mortality ratio in Ethiopia $353 / 100,000$.

Worldwide, maternal morbidity and mortality is alarmingly decrease, however in developing countries, especially sub-Saharan Africa frontline maternal death is caused by hemorrhage due to infrastructure limitation, lack of skill birth attendants, inappropriate management of active third stage of labor, [2].

Third stage of labor is the period after the fetus is delivered until the placenta completely removed. It is the easiest and shortest time, but dangerous as most maternal deaths were occurred [3].

Active management of third stage of labor involves the obstetric care providers to carry out three interrelated but independent processes: - Prophylactic administration of an uterotonic agent, Controlled cord traction and uterine massage. Active management of third stage of labor is an interventions needed to reduce maternal death due to PPH [4].

FIGO-ICM Recommends to use uterotonic drugs immediately following delivery of the fetus, controlled cord traction and uterine massage immediately after delivery of the placenta, followed by massage of the uterus every $15 \mathrm{~min}$ for $2 \mathrm{~h}$ to assess the continued need for massage [5].

Active management of third stage of labor is a proven solution to prevent unnecessary procedures and complications, such as manual removal of the placenta and postpartum hemorrhage [6].

Since all parturient women are at risk for PPH, obstetric care providers need to possess the necessary knowledge and skills of active management of the third stage of labor properly to prevent PPH [7].

The WHO technical update, assures that now a days the most effective approach to prevent PPH is active management of the third stage of labor (AMTSL) [8].

Effective use of AMTSL in reducing PPH and the need for $\mathrm{PPH}$ treatment has been investigated by a number of large trials. The Hinchinbrook 12 randomized control trials provided evidence that AMTSL significantly reduces postpartum hemorrhage, decreases blood loss and decreases the need for blood transfusions [2].
The AMTSL practice of obstetric care providers in developing countries is not in line with what is recommended by FIGO because of certain factors like knowledge, qualification, training, and other demographic factors. The practice of AMTSL according to the FIGO/ ICM recommendations in Ethiopia was only 5\% of all observed deliveries [5].

The aimed of this study is to assess knowledge, practice and associated factors of obstetric care providers (amongst midwives, nurses and health officers) on active management of third stage of labor in Sidama Zone, South Ethiopia.

\section{Methods}

An Institution based cross-sectional study was conducted among obstetric care providers in Sidama Zone from December 1-30, 2015. Sidama zone is one of the zone found in southern nation's nationalities and peoples region (SNNPR) of Ethiopia.

According to Sidama zone health department, the total population in 2014/2015 is expected to be $3,676,576$. The health institutions which are found in the zone include three governmental hospitals, 130 governmental health centers, 524 posts. Regarding human resource for health, the zone has 1857 obstetrics care providers.

Out of 19 Woredas (districts), from the Zone seven were selected by simple random sampling techniques [9]. The study population was randomly selected obstetric care providers. The sample size was determined using single population proportion formula at $95 \%$ of confidence interval with assumption of prevalence of AMTSL practice in Ethiopia 5\% [5] with $(\alpha=0.05), 3 \%$ marginal error $(d=0.03)$.

Multistage stage sampling method was employed by using design effect of 2 and 10\% non-response response. The final sample size was 528 obstetric care providers. To collect the data, initially all public health institution in Sidama zone from selected Districts were listed and identified. The participants were allocated proportionally to each public health institution and were selected by using simple random sampling technique from each public health institution. Obstetric care providers who had service greater than 6 month were participated in the study.

The structured interviewer administered questionnaires were included sociodemographic characteristics, personal characteristics and knowledge while observational checklist for skill part assessment were used as data collection instruments.

Obstetric care provider who knew all AMTSL components, right time of oxytocin administration and cord clamping were considered as knowledgeable and 
the obstetric care provider who administered oxytocin with in $1 \mathrm{~min}$, apply CCT and perform uterine massage considered as skilled.

Pretest was done on 5\% obstetric care providers working out of the selected health to check clarity, length and completeness of the questionnaires and observation check list. Based on this necessary correction was done accordingly.

Data was collected by face to face interview using a structured and pre-tested questionnaire to assess knowledge and observation check lists for practice assessment.

Both interview and observation were used for the same participant, interview was administered to assess the sociodemographic characteristics and knowledge of the participant. After interview, verbal consent was obtained from the parturient mothers, and the participant was observed while managing third stage of labor.

Interview and observation were performed by obstetric care provider data collectors. Both sexes were participated in data collection. Seven (07) obstetric care providers who have $\mathrm{BEmONC}$ training were recruited and training was given for 01 days on the objective, relevance of the study, confidentiality of information, respondent rights, informed consent, and technique of interview, 02 Health professional who have 1st degree (BSC nurse, midwife or $\mathrm{HO}$ ) were trained and supervise the data collection. Data entry was done by using EPI Info 3.5.1 and exported to SPSS version 20.0 software package for analysis. The presence of association between independent and dependent variables was assessed using odds ratio with $97 \%$ confidence interval by applying logistic regression model.

Ethical clearance was obtained from College of Medicine and Health Sciences ethical review committee, Hawassa University. Formal letter of cooperation was written for Sidama Zone Health Department and Sidama zone selected District Health Offices. After informing the objective of the study, consent was obtained voluntarily from each study subject.

\section{Results}

\section{Socio-demographic characteristic and experiences of obstetric care providers}

A total of 528 obstetric care providers were participated in the study, with $96.4 \%$ response rate. Out of the total respondents, $75.4 \%(n=398)$ were females and the age of participants were from 22 to 45 years old. The mean age of the study population was 26.4 with SD 3.05 years. Sidama was a dominant ethnic group, which accounted for $49.6 \%(n=262)$ (Table 1).

\section{Knowledge of obstetrics care providers on active management of third stage of labor}

The knowledge of the obstetrics care providers towards active management of third stage of labor were $37.7 \%(n=199)$ (Table 2$)$.

Table 1 Socio-demographic characteristics of the obstetric care providers

\begin{tabular}{|c|c|c|c|}
\hline Variables & & $\begin{array}{l}\text { Frequency } \\
(n=528)\end{array}$ & Percentage \\
\hline \multirow[t]{2}{*}{ Sex } & Male & 130 & 24.6 \\
\hline & Female & 398 & 75.4 \\
\hline \multirow[t]{3}{*}{ Age } & $20-30$ & 461 & 87.3 \\
\hline & $31-40$ & 57 & 10.8 \\
\hline & $41-50$ & 10 & 1.9 \\
\hline \multirow[t]{4}{*}{ Marital status } & Single & 258 & 48.9 \\
\hline & Married & 249 & 47.2 \\
\hline & Divorced & 16 & 3 \\
\hline & Widowed & 5 & 0.9 \\
\hline \multirow[t]{5}{*}{ Ethnicity } & Sidama & 262 & 49.6 \\
\hline & Amhara & 104 & 19.7 \\
\hline & Oromo & 125 & 23.7 \\
\hline & Tigre & 20 & 3.8 \\
\hline & Others $^{\circledast}$ & 17 & 3.2 \\
\hline \multirow[t]{4}{*}{ Religion } & Protestant & 216 & 40.9 \\
\hline & Orthodox & 233 & 44.1 \\
\hline & Muslim & 38 & 7.2 \\
\hline & Catholic & 41 & 7.8 \\
\hline \multirow[t]{2}{*}{ Work place } & Health center & 483 & 91.5 \\
\hline & Hospital & 45 & 8.5 \\
\hline \multirow[t]{6}{*}{ Profession } & Health officer & 30 & 5.7 \\
\hline & BSc midwife & 66 & 12.5 \\
\hline & $\begin{array}{l}\text { Diploma } \\
\text { midwife }\end{array}$ & 330 & 62.5 \\
\hline & BSc Nurse & 40 & 7.6 \\
\hline & $\begin{array}{l}\text { Diploma } \\
\text { Nurse }\end{array}$ & 61 & 11.6 \\
\hline & Others $\boldsymbol{\bullet}$ & 1 & 0.2 \\
\hline \multirow{2}{*}{$\begin{array}{l}\text { AMTSL related In/pre service } \\
\text { training }\end{array}$} & Yes & 374 & 70.8 \\
\hline & No & 154 & 29.2 \\
\hline \multirow{2}{*}{$\begin{array}{l}\text { Conduciveness of delivery } \\
\text { room }\end{array}$} & Yes & 467 & 88.4 \\
\hline & No & 61 & 11.6 \\
\hline \multirow[t]{2}{*}{ Adequate oxytocic drugs } & Yes & 488 & 92.4 \\
\hline & No & 40 & 7.6 \\
\hline
\end{tabular}

Others $^{\oplus}$ : Wolayta, Hadya, Kembata Others $\Theta$ Public Nurse 
Table 2 Knowledge of the obstetric care providers on active management of third stage of labor

\begin{tabular}{|c|c|c|c|}
\hline Variables & & Frequency & Percent \\
\hline \multirow[t]{4}{*}{ Uterotonic drugs know } & Oxytocin & 439 & 83 \\
\hline & Ergometrine & 57 & 10.8 \\
\hline & Misoprostol & 18 & 3.4 \\
\hline & All & 15 & 2.8 \\
\hline \multirow[t]{4}{*}{ Dose of oxytocin know } & $0.5 \mathrm{mg}$ & 6 & 1.0 \\
\hline & $10 \mathrm{IU}$ & 492 & 93.2 \\
\hline & $10 \mathrm{mg}$ & 26 & 4.9 \\
\hline & $0.5 \mathrm{IU}$ & 5 & 0.9 \\
\hline \multirow{2}{*}{$\begin{array}{l}\text { Recommended rout of } \\
\text { oxytocin know }\end{array}$} & IV & 34 & 6.4 \\
\hline & $\mathrm{IM}$ & 494 & 93.6 \\
\hline \multirow[t]{3}{*}{$\begin{array}{l}\text { Time of uterotonic drug } \\
\text { administration know }\end{array}$} & $\begin{array}{l}\text { After the delivery } \\
\text { of anterior } \\
\text { shoulder }\end{array}$ & 33 & 6.2 \\
\hline & $\begin{array}{l}\text { Within one } \\
\text { minute after } \\
\text { delivery of baby }\end{array}$ & 451 & 85.3 \\
\hline & $\begin{array}{l}\text { Within three } \\
\text { minutes }\end{array}$ & 45 & 8.5 \\
\hline \multirow{5}{*}{$\begin{array}{l}\text { Mentioned essential } \\
\text { components of active } \\
\text { management of third stage of } \\
\text { labor }\end{array}$} & $\begin{array}{l}\text { Administer } \\
\text { uterotonic drugs }\end{array}$ & 61 & 11.5 \\
\hline & $\begin{array}{l}\text { Apply counter } \\
\text { cord traction }\end{array}$ & 102 & 19.3 \\
\hline & Uterine massage & 59 & 11.2 \\
\hline & All & 307 & 58 \\
\hline & Knowledgeable & 199 & 37.7 \\
\hline Knowledge & $\begin{array}{l}\text { Not } \\
\text { knowledgeable }\end{array}$ & 329 & 62.3 \\
\hline
\end{tabular}

\section{Practice of obstetrics care providers on active} managements of third stage of labor

The practice of the obstetrics care providers towards active management of third stage of labor were $32.8 \%(n=173)$ (Table 3).

\section{Factors associated with obstetric care provider's knowledge to wards AMTSL}

Profession and year of graduation were factors which associate with knowledge of obstetric care provider's towards active management of third stage of labor (Table 4).

\section{Factors associated with obstetric care provider's practice to wards AMTSL}

Pre/in service training was associated with the practice of obstetric care providers to wards active management of third stage of labor (Table 5).

In this study $11.4 \%(n=60)$ of the obstetric care providers were clamp the cord within the recommended time which is within 2-3 $\mathrm{min}$ (Fig. 1).
Table 3 Practices of the obstetric care providers on active management of third stage of labor

\begin{tabular}{|c|c|c|c|}
\hline Variables & & Frequency & Percent \\
\hline \multirow{2}{*}{$\begin{array}{l}\text { Abdomen palpated to rule out the } \\
\text { presence of second baby }\end{array}$} & Yes & 331 & 62.7 \\
\hline & No & 197 & 37.3 \\
\hline \multirow[t]{4}{*}{ Uterotonic drugs given } & Oxytocin & 432 & 81.8 \\
\hline & Ergometrine & 61 & 11.6 \\
\hline & Misoprostol & 30 & 5.7 \\
\hline & Not given & 5 & 0.9 \\
\hline \multirow[t]{4}{*}{ Dose of uterotonic drugs given } & $0.5 \mathrm{mg}$ & 24 & 4.5 \\
\hline & $10 \mathrm{IU}$ & 486 & 96.6 \\
\hline & $0.5 \mathrm{mg}$ & 12 & 2.3 \\
\hline & Others & 6 & 1.1 \\
\hline \multirow[t]{3}{*}{ Route of uterotonic drugs given } & IM & 519 & 97.2 \\
\hline & IV & 9 & 1.7 \\
\hline & Oral & 6 & 1.1 \\
\hline \multirow{2}{*}{$\begin{array}{l}\text { Wait uterine contraction } 2-3 \text { min to } \\
\text { apply CCT }\end{array}$} & Yes & 243 & 46 \\
\hline & No & 285 & 54 \\
\hline \multirow[t]{2}{*}{ Wait gush of blood } & Yes & 283 & 53.6 \\
\hline & No & 245 & 46.4 \\
\hline \multirow[t]{2}{*}{ Counter cord traction applied } & Yes & 472 & 89.4 \\
\hline & No & 56 & 10.6 \\
\hline \multirow{2}{*}{$\begin{array}{l}\text { Placenta supported by two hands } \\
\text { during placenta delivery }\end{array}$} & Yes & 421 & 79.7 \\
\hline & No & 107 & 20.3 \\
\hline \multirow{2}{*}{$\begin{array}{l}\text { Membrane extracted gently with } \\
\text { lateral movement }\end{array}$} & Yes & 293 & 55.5 \\
\hline & No & 235 & 44.5 \\
\hline \multirow{2}{*}{$\begin{array}{l}\text { Uterine massage immediately after } \\
\text { delivery of placenta }\end{array}$} & Yes & 227 & 43 \\
\hline & No & 301 & 57 \\
\hline \multirow[t]{2}{*}{ Uterine relaxation ensured } & Yes & 161 & 30.5 \\
\hline & No & 367 & 69.5 \\
\hline \multirow{2}{*}{$\begin{array}{l}\text { Inform and demonstrate the mother } \\
\text { massage uterus }\end{array}$} & Yes & 196 & 37.1 \\
\hline & No & 332 & 62.9 \\
\hline \multirow[t]{2}{*}{ Skill } & Skilled & 173 & 32.8 \\
\hline & Not skilled & 355 & 67.2 \\
\hline
\end{tabular}

Eighty eight point $4 \%(n=467)$ of the delivery rooms were conducive to apply active third stage management (Fig. 2).

\section{Discussion}

The available reports and this study showed that in Ethiopia the knowledge and practice of obstetric care providers towards active management of third stage of labor is unsatisfactory. Among the participants $37.7 \%(n=199)$ of the obstetric care providers were knowledgeable on managing of third stage of labor actively. This finding is higher than the study conducted in south Nigeria and Tanzania 28.3\% and $9 \%$ respectively $[10,11]$. Profession and year of 
Table 4 Factors associated with obstetrics care providers' knowledge on active third stage management of labor

\begin{tabular}{|c|c|c|c|c|c|c|}
\hline \multirow[t]{2}{*}{ Characteristics } & & \multicolumn{2}{|c|}{ AMTSL knowledge } & \multicolumn{2}{|l|}{$\mathrm{OR}(97 \% \mathrm{Cl})$} & \multirow[t]{2}{*}{$P$ value } \\
\hline & & Yes & No & Crude & Adjusted & \\
\hline \multirow[t]{2}{*}{ Sex } & Female & 154 & 244 & $1.2(0.75-1.88)$ & $0.86(0.54-1.34)$ & 0.47 \\
\hline & Male & 45 & 85 & 1.00 & & \\
\hline \multirow[t]{2}{*}{ Age } & $20-30$ & 171 & 289 & $1.14(0.64-2.04)$ & $0.90(0.50-1.62)$ & 0.70 \\
\hline & $>30$ & 28 & 40 & 1.00 & & \\
\hline \multirow[t]{2}{*}{ Marital status } & Single & 114 & 144 & $1.72(0.65-1.42)$ & $0.92(0.61-1.40)$ & 0.66 \\
\hline & Married & 85 & 185 & 1.00 & & \\
\hline \multirow[t]{2}{*}{ Work place } & Hospital & 22 & 23 & $0.55(0.28-1.08)$ & $0.60(0.30-1.24)$ & 0.13 \\
\hline & Health center & 307 & 176 & 1.00 & & \\
\hline \multirow[t]{2}{*}{ Profession } & Midwife & 259 & 167 & $1.37(1.07-2.60)^{*}$ & $1.76(0.33-0.87)^{\mathrm{a}}$ & 0.007 \\
\hline & Others $\Theta$ & 70 & 62 & 1.00 & & \\
\hline \multirow[t]{2}{*}{ Year of graduation } & $2005-2007$ & 136 & 193 & $1.55(1.00-2.29)^{*}$ & $0.67(0.46-0.98)^{a}$ & 0.036 \\
\hline & Before 2005 & 62 & 136 & 1.00 & & \\
\hline \multirow[t]{2}{*}{ Year of experience } & $1 / 2-2$ years & 105 & 159 & $1.19(0.80-1.76)$ & $0.84(0.56-1.27)$ & 0.36 \\
\hline & $>2$ years & 94 & 170 & 1.00 & & \\
\hline \multirow[t]{2}{*}{ Receiving training } & Yes & 59 & 95 & $1.04(0.63-1.48)$ & $0.86(0.46-1.58)$ & 0.58 \\
\hline & No & 140 & 234 & 1.00 & & \\
\hline \multirow[t]{2}{*}{ Trained topic related to AMTSL } & Yes & 96 & 151 & $1.10(0.75-1.62)$ & $0.99(0.56-1.76)$ & 0.96 \\
\hline & No & 103 & 176 & 1.00 & & \\
\hline
\end{tabular}

*P-value $<0.05$,

${ }^{\text {a }}$ Adjusted for socio demographic characteristics and some concepts of AMTSL

Others $\Theta$ : Health officers, BSc/diploma nurses, public nurse

graduation were the factors which associate with obstetric care provider's knowledge towards active management of third stage of labor. Even observational studies are exposed to observational bias, utilization of both structured interviewer administered questionaries and observation check list is considered as strength of this study. This study is the first of its kind in southern Ethiopia which includes observational check list to assess the actual practice of obstetric care providers towards active management of third stage of labor. Based on the observation the practice of obstetric care providers were not satisfactory in this study even it is better from the previous findings in Ethiopia and Nigeria $[5,9]$. Almost all the obstetric care providers were rid of the placenta after administration of uterotonic drugs, like that of Australia, Holland and United Kingdom practice, but different from some United States and Canada which advocates withholding uterotonic administration until the placenta is delivered [12]. All obstetric acre providers were used oxytocin as an uterotonic drug for AMTSL which is slightly different from a study conducted in Istanbul, Turkey [6]. Most of the obstetric care providers check presence of second twine before administration of oxytocin which is better than Istanbul Turkey practice [6]. Majority of the participants were observed while correctly apply counter cord traction practice but half of them were not wait uterine contraction like that of Nepal [13] Practice.
Participants who got pre/in service training were observed while correctly practicing AMTSL than who did not have training which indicates AMTSL related training is needed.

In this study majority of the obstetric care providers were midwives which is totally different from a study conducted in Ethiopia, which concludes nurses performed most (61\%) in Ethiopia [5]. Physicians were not observed during active management of third stage of labor, this might be due to Physicians tend to manage more complicated third stages. Most of our participants were not clamp the cord with the recommended time which is within 2-3 min. In Albanian maternity hospital the practice is within $20 \mathrm{~s}$ [14]. There was no problem on delivery room conduciveness and availanlity of oxytocic drugs to practice AMTSL in our study area.

\section{Conclusion and recommendation}

The knowledge and practice of obstetric care providers towards active management of third stage of labor can be improved with appropriate interventions like inservice trainings. This study also clearly showed that the knowledge and practice of obstetric care providers to wards AMTSL which needs immediate attention of Universities and health science colleges better to revise their obstetrics course contents, health institutions and zonal health office need to arrange trainings for their obstetrics care providers to enhance skill. 
Table 5 Factors associated with obstetrics care providers' practices on active third stage management of labor

\begin{tabular}{|c|c|c|c|c|c|c|}
\hline \multirow[t]{2}{*}{ Characteristics } & & \multicolumn{2}{|c|}{ AMTSL Practice } & \multicolumn{2}{|l|}{ OR $(97 \% \mathrm{Cl})$} & \multirow[t]{2}{*}{$P$-value } \\
\hline & & Yes & No & Crude & Adjusted & \\
\hline \multirow[t]{2}{*}{ Sex } & Male & 45 & 85 & $1.12(0.70-1.78)$ & $1.30(0.78-2.16)$ & 0.27 \\
\hline & Female & 128 & 270 & 1.00 & 1.00 & \\
\hline \multirow[t]{2}{*}{ Age } & $20-30$ & 157 & 303 & $1.68(0.29-1.09)$ & $1.75(0.89-3.43)$ & 0.07 \\
\hline & $>30$ & 16 & 52 & 1.00 & 1.00 & \\
\hline \multirow[t]{2}{*}{ Marital status } & Single & 108 & 191 & $1.43(0.46-1.06)$ & $0.73(0.48-1.11)$ & 0.10 \\
\hline & Married & 65 & 164 & 1.00 & & \\
\hline \multirow[t]{2}{*}{ Profession } & Midwives & 125 & 271 & $0.81(0.78-1.96)$ & $0.73(0.45-1.18)$ & 0.15 \\
\hline & Others & 48 & 84 & 1.00 & 1.00 & \\
\hline \multirow[t]{2}{*}{ Conduciveness of delivery room } & Yes & 147 & 320 & $0.62(0.34-1.13)$ & $0.66(0.35-1.25)$ & 0.15 \\
\hline & No & 26 & 35 & 1.00 & 1.00 & \\
\hline \multirow[t]{2}{*}{ Place of work } & Hospital & 20 & 25 & $1.73(0.29-1.15)$ & $0.55(0.27-1.10)$ & 0.06 \\
\hline & Health center & 153 & 330 & 1.00 & 1.00 & \\
\hline \multirow[t]{2}{*}{ Year of graduation } & $2005-2007$ & 102 & 227 & $0.81(0.54-1.22)$ & $1.28(0.84-1.95)$ & 0.21 \\
\hline & Before 2005 & 71 & 128 & 1.00 & 1.00 & \\
\hline \multirow[t]{2}{*}{ Experience Year } & $1 / 2-2$ year & 87 & 177 & $1.02(0.68-1.41)$ & $0.97(0.67-1.42)$ & 0.91 \\
\hline & $>2$ year & 86 & 178 & 1.00 & 1.00 & \\
\hline \multirow[t]{2}{*}{ Receiving training } & Yes & 143 & 231 & $2.56(1.56-4.20)^{*}$ & $2.67(1.60-4.50)^{a}$ & 000 \\
\hline & No & 30 & 124 & 1.00 & 1.00 & \\
\hline \multirow[t]{2}{*}{ Training topic related to AMTSL } & Yes & 98 & 183 & $1.23(0.82-1.84)$ & $1.28(0.84-1.95$ & 0.20 \\
\hline & No & 75 & 172 & 1.00 & 1.00 & \\
\hline
\end{tabular}

\section{* $P$-value $<0.05$}

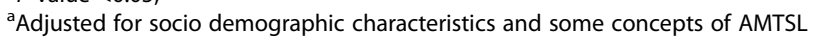
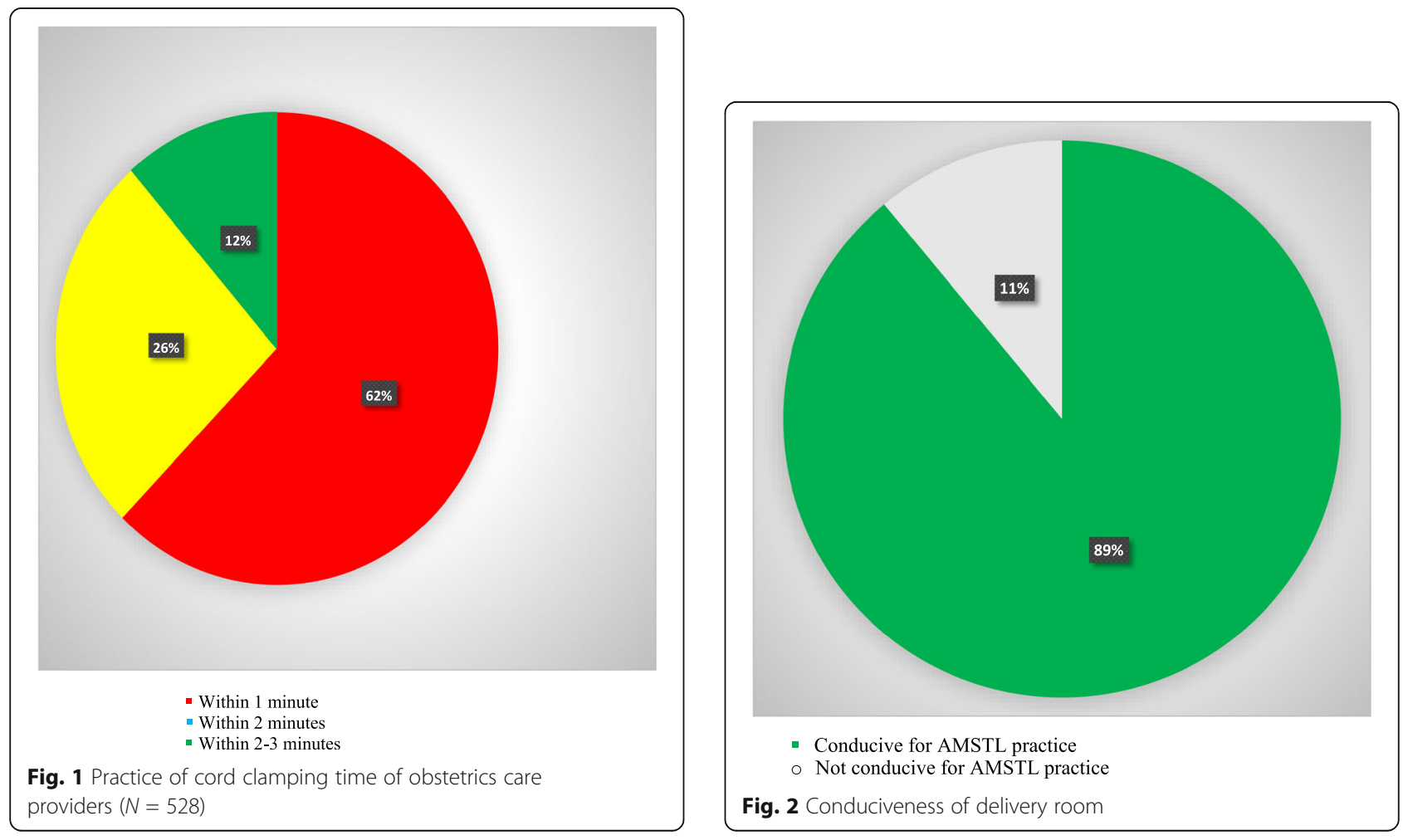


\section{Abbreviation}

AMTSL: Active management of third stage of labor; AOR: Adjusted odds ratio; BEmONC: Basic emergency obstetrics and newborn care; E.C: E Ethiopian calendar; FIGO: Federation of international gynecology and obstetrics; ICM: International cooperation of midwifery; PPH: Postpartum hemorrhage; SNNPRS: Southern nation nationalities people regional state; WHO: World health organization

\section{Acknowledgements}

We are very grateful to Hawassa University for approval of ethical clearance, technical and financial support of this study. Then, we would like to thank all obstetrics care providers who participated in this study for their commitment in responding to our interviews and consent for observations. Finally, we are also grateful to the Sidama zone health department and Sidama zone selected District health offices for their assistance and permission to undertake the research.

\section{Competent interests}

The authors declare that they have no competing interests.

\section{Funding}

This research were funded by Hawassa University for academic staff.

\section{Availability of data and materials}

We send all which is available as, there is not remaining data and materials.

\section{Authors' contributions}

ZT wrote the proposal, participated in data collection, analyzed the data and drafted the paper. ZY and AA approved the proposal with some revisions, participated in data analysis and revised subsequent drafts of the paper. All authors read and approved the final manuscript.

\section{Ethics approval and consent to participate}

Ethical clearance was obtained from the Institutional Review Board of the Hawassa University. Communication with the different District health office administrators were made through formal letter obtained from the Hawassa University. After the purpose and objective of the study have been informed, written and verbal consent was obtained from each study participant. Participants were also be informed that participation was on voluntary basis and they can withdraw from the study at any time if they were not comfortable about the questionnaire. In order to keep confidentiality the information was maintained throughout by excluding names as identification in the questionnaire and kept their privacy during the observation by observing them alone.

\section{Consent for publication}

Not applicable.

\section{Publisher's Note}

Springer Nature remains neutral with regard to jurisdictional claims in published maps and institutional affiliations.

\section{Author details}

'School of Nursing and Midwifery, College of Medicine and health sciences, Hawassa University, Hawassa, Ethiopia. ${ }^{2}$ School of Public and Environmental Health, College of Medicine and health sciences, Hawassa University, Hawassa, Ethiopia.

Received: 6 September 2016 Accepted: 1 September 2017

Published online: 07 September 2017

\section{References}

1. Organization WH, UNICEF. Trends in maternal mortality: 1990-2015: estimates from WHO, UNICEF, UNFPA, World Bank Group and the United Nations Population Division. 2015.

2. Organization WH. Maternal mortality in 2005. Estimates developed by WHO, UNICEF, UNFPA, and The World Bank. 2010.

3. Deepak NN, Mirzabagi E, Koski A, Tripathi V. Knowledge, Attitudes, and Practices Related to Uterotonic Drugs during Childbirth in Karnataka, India: A Qualitative Research Study. PLoS One. 2013;8(4):e62801.
4. Ramadhani F. Midwives' competency for implementation of active management of third stage of labor in Dar es salaam municipal hospitals. Tanzania: Muhimbili University of Health and Allied Sciences; 2011.

5. Taylor U, Delorme P, Miller S. FIGO Guidelines: Prevention and Treatment of Postpartum Hemorrhage in Low-Resource Settings.

6. Stanton C, Armbruster D, Knight R, Ariawan I, Gbangbade S, Getachew A, et al. Use of active management of the third stage of labour in seven developing countries. Bull World Health Organ. 2009;87(3):207-15.

7. Tan WM, Klein MC, Saxell L, Shirkoohy SE, Asrat G. How do physicians and midwives manage the third stage of labor? Birth. 2008;35(3):220-9.

8. Leduc D, Senikas V, Lalonde AB, Ballerman C, Biringer A, Delaney M, et al. Active management of the third stage of labour: prevention and treatment of postpartum hemorrhage. JOGC. 2009;31(10):980-93.

9. Salvador E. Active Management of the Third State of Labor Is Rare in Some Developing Countries. Bull World Health Organ. 2009:87(3):207-15.

10. Maughan KL, Heim SW, Galazka SS. Preventing postpartum hemorrhage: managing the third stage of labor. Am Fam Physician. 2006;73(6):1025-8.

11. Oladapo OT, Fawole AO, Loto OM, Adegbola O, Akinola Ol, Alao MO, et al. Active management of third stage of labour: a survey of providers' knowledge in southwest Nigeria. Arch Gynecol Obstet. 2009;280(6):945-52.

12. Bimbashi A, Ndoni E, Dokle A, Duley L. Care during the third stage of labour: obstetricians views and practice in an Albanian maternity hospital. BMC Pregnancy Childb. 2010;10(1):4.

13. Prick BW, Vos AA, Hop WC, Bremer HA, Steegers EA, Duvekot JJ. The current state of active third stage management to prevent postpartum hemorrhage: a cross-sectional study. Acta Obstet Gynecol Scand. 2013 Nov; 92(11):1277-83.

14. Oladapo OT, Akinola Ol, Fawole AO, Adeyemi AS, Adegbola O, Loto OM, et al. Active management of third stage of labor: evidence versus practice. Acta Obstet Gynecol Scand. 2009;88(11):1252-60.

\section{Submit your next manuscript to BioMed Central and we will help you at every step:}

- We accept pre-submission inquiries

- Our selector tool helps you to find the most relevant journal

- We provide round the clock customer support

- Convenient online submission

- Thorough peer review

- Inclusion in PubMed and all major indexing services

- Maximum visibility for your research

Submit your manuscript at www.biomedcentral.com/submit
Biomed Central 